\title{
Genomic sequencing in clinical trials
}

\author{
Karen K Mestan ${ }^{1 *}$, Leonard Ilkhanoff ${ }^{2}$, Samdeep Mouli ${ }^{3}$ and Simon Lin ${ }^{4}$
}

\begin{abstract}
Human genome sequencing is the process by which the exact order of nucleic acid base pairs in the 24 human chromosomes is determined. Since the completion of the Human Genome Project in 2003, genomic sequencing is rapidly becoming a major part of our translational research efforts to understand and improve human health and disease. This article reviews the current and future directions of clinical research with respect to genomic sequencing, a technology that is just beginning to find its way into clinical trials both nationally and worldwide. We highlight the currently available types of genomic sequencing platforms, outline the advantages and disadvantages of each, and compare first- and next-generation techniques with respect to capabilities, quality, and cost. We describe the current geographical distributions and types of disease conditions in which these technologies are used, and how next-generation sequencing is strategically being incorporated into new and existing studies. Lastly, recent major breakthroughs and the ongoing challenges of using genomic sequencing in clinical research are discussed.
\end{abstract}

Keywords: Clinical trial, DNA, sequencing, human genome, bioinformatics

\section{Introduction}

Human genome sequencing, the process by which the exact order of nucleic acid base pairs in the 24 human chromosomes is determined, was the most significant technical challenge of the Human Genome Project. Completed in 2003, the 13-year project identified 20,000 to 25,000 genes and determined the sequence of the 3 billion chemical base pairs that make up human DNA as well as the regions that control them. Since then, improvements in sequencing speed, reliability, and cost have been the ongoing goals. Hence, genomic sequencing is rapidly becoming a major part of our translational research efforts to understand and improve human health and disease. With the numerous advances in genomic sequencing, there has been a dramatic increase in the number of clinical trials now using this technology to study key disease outcomes [1].

The objective of this review is to familiarize the translational investigator with genomic sequencing technologies as they apply to clinical trials. We describe the currently available types of genomic sequencing platforms, outline the advantages and disadvantages of each, and compare first- and next-generation techniques with

\footnotetext{
* Correspondence: k-mestan@northwestern.edu

'Department of Pediatrics, Division of Neonatology, Northwestern University Feinberg School of Medicine, Chicago, IL, USA

Full list of author information is available at the end of the article
}

respect to capabilities, quality, and cost. To illustrate the recent impact and widespread movement of genomic sequencing into clinical and translational research, we provide a summary of the types and distribution of clinical studies that are using genomic sequencing to enhance the understanding of complex pathophysiology and identify important biomarkers of both rare and common diseases. We provide some key examples of clinical trials in which translational researchers are utilizing this technology to better identify and individualize the management of high-risk patients, and to achieve major breakthroughs in drug development.

\section{Features of First- and Next-Generation Sequencing}

So rapid are the advances in genomic sequencing technology that the methods are commonly referred to as first- and next-generation sequencing (NGS). Sanger sequencing, developed in the 1990s, was the earliest method used to sequence human DNA. In fact, it was Sanger technology that was used to sequence the human genome in the Human Genome Project. It is often referred to as "first-generation sequencing" because it revolutionized how a single lab could sequence millions (rather than thousands) of base pairs. Sanger sequencing is a multi-channel capillary approach that allows relatively rapid DNA sequencing. Even 
though the newer platforms are much faster and cheaper, Sanger sequencing remains in many respects the "gold standard" for smaller validation studies, and remains the only widely used platform that can sequence relatively long sequences of DNA-up to 1,000 nucleotides in length (Table 1).

Several second generation sequencing technologies have emerged over the past ten years, including Roche 454, Illumina Genome Analyzer (GA), and Applied Biosystems (ABI) SOLiD. These platforms are able to generate more sequence and are substantially less expensive than the original Sanger methods (Table 1). They can also handle more complex and smaller genomes, sequence mRNA, copy number variants (CNV) and single nucleotide polymorphisms (SNPs) to account for structural variations (Table 2). In addition to whole genome sequencing, NGS technologies have been successfully used in chromatin immunoprecipitation (ChIP)sequencing to identify key binding sites of DNA-associated proteins, [2,3] and RNA-sequencing for mammalian and human tissue transcriptomes.[4-6] Due to the cost-effectiveness and versatility of NGS as compared to first-generation sequencing, NGS approaches are poised to emerge as a dominant genomics technology in patient-oriented research. Specifically, there is considerable interest in employing NGS platforms for targeted sequencing of specific candidate genes and sequencing of SNPs identified through gene-association studies. With the declining cost of NGS technology, sequencing of the entire human exome in large numbers of individuals is now feasible and promising [7-9].
Table 1 summarizes the advantages and disadvantages of Sanger, Roche 454, Illumina, and SOLiD platforms [10]. It is important to note that there is no single platform that is ideal for every application, and therefore, all four of these platforms are still widely used. With the lower cost and more rapid turnover of the Illumina and SOLiD platforms, the capacity for read length is limited. Nevertheless, the rapid adoption of genome sequencing has been fueled by rapid dropping of cost, and this may be the main determining factor in which platforms are used for any given clinical trial. The commercial price of a whole genome sequencing declined from more than $\$ 50,000$ in 2009 to less than $\$ 5,000$ in $2011[7,11]$. It is anticipated that full genome sequencing will soon cost less than $\$ 1,000$ [12]. Translational investigators can anticipate ongoing improvements in the existing technologies, and the emergence of newer approaches to offset cost while improving both accuracy, read length, and turnover [13]. For example, Pacific Biosciences released the first "third generation" sequencer this year, which incorporates novel, single-molecule sequencing techniques and advanced analytics. This system can deliver read lengths of $>1,000$ bases on average, with results obtained in less than a day, as compared to the current second-generation turnaround of $>1$ weeks [14].

\section{Genomics in Human Disease: Whole, Exome, and Transcriptome Sequencing}

There are currently three widely adopted approaches to sequencing: whole genome, exome, and transcriptome sequencing. The specific approach being used for any

Table 1 Summary of throughput, length, quality, and cost of current versions of genomic sequencing

\begin{tabular}{|c|c|c|c|c|c|c|c|c|}
\hline Platform & Throughput & Length & Quality & Cost & Applications & Sources of error & Advantages & Disadvantages \\
\hline Sanger & $6 \mathrm{Mb} /$ day & $1,000 \mathrm{nt}$ & $10^{-4}-10^{-5}$ & $\begin{array}{c}\sim \\
\$ 500 / \\
\mathrm{Mb}\end{array}$ & $\begin{array}{l}\text { Small sample sizes, genomes, } \\
\text { SNPs, long haplotypes, low } \\
\text { complexity regions, etc. }\end{array}$ & $\begin{array}{c}\text { Polymerase/ } \\
\text { amplification, low } \\
\text { intensities/missing } \\
\text { termination variants, } \\
\text { contaminant sequences }\end{array}$ & $\begin{array}{l}\text { Longest reads, gold } \\
\text { standard for } \\
\text { validations }\end{array}$ & $\begin{array}{l}\text { High cost, low } \\
\text { throughput }\end{array}$ \\
\hline $\begin{array}{c}\text { 454/ } \\
\text { Roche }\end{array}$ & 750 Mb/day & $400 \mathrm{nt}$ & $10^{-3}-10^{-4}$ & $\begin{array}{c}\sim \$ 20 / \\
\mathrm{Mb}\end{array}$ & $\begin{array}{c}\text { Complex genomes, SNPs, } \\
\text { structural variation, indexed } \\
\text { samples, small RNAs, mRNAs, } \\
\text { etc. }\end{array}$ & $\begin{array}{l}\text { Amplification, mixed } \\
\text { beads, intensity } \\
\text { thresholding, } \\
\text { homopolymers, } \\
\text { phasing, neighbor } \\
\text { interference }\end{array}$ & $\begin{array}{l}\text { Longer reads, easier } \\
\text { to assemble }\end{array}$ & $\begin{array}{l}\text { Medium } \\
\text { throughput, } \\
\text { expensive, } \\
\text { indel errors } \\
\text { more likely }\end{array}$ \\
\hline Illumina & 5,000 Mb/day & $100 \mathrm{nt}$ & $10^{-2}-10^{-3}$ & $\begin{array}{l}\sim \\
\$ 0.50 / \\
\mathrm{Mb}\end{array}$ & $\begin{array}{c}\text { Complex genomes, counting } \\
\text { (SAGE, CNV Chip, small RNA), } \\
\text { mRNAs, structural variation, } \\
\text { bisulfite data, indexing SNPs, } \\
\text { etc. }\end{array}$ & $\begin{array}{l}\text { Amplification, mixed } \\
\text { clusters/neighbor } \\
\text { interference, phasing, } \\
\text { base labeling }\end{array}$ & $\begin{array}{c}\text { Lower cost, widely } \\
\text { adopted platform, } \\
\text { most well- } \\
\text { developed } \\
\text { bioinformatics } \\
\text { efforts }\end{array}$ & $\begin{array}{l}\text { Higher base } \\
\text { substitution } \\
\text { error rate, } \\
\text { shorter reads }\end{array}$ \\
\hline SOLiD & $5,000 \mathrm{Mb} /$ day & $75 \mathrm{nt}$ & $10^{-2}-10^{-3}$ & $\begin{array}{c}\sim \\
\$ 0.50 / \\
\mathrm{Mb}\end{array}$ & $\begin{array}{c}\text { Complex small genomes, } \\
\text { counting (SAGE, ChiP, small } \\
\text { RNA, CNV), SNPs, mRNAs, } \\
\text { structural variation, indexing, } \\
\text { etc. }\end{array}$ & $\begin{array}{l}\text { Amplification, mixed } \\
\text { beads, phasing, signal } \\
\text { decline, neighbor } \\
\text { interference }\end{array}$ & $\begin{array}{c}\text { Lower cost, 2-base } \\
\text { encoding } \\
\text { chemistry, higher } \\
\text { per-base accuracy }\end{array}$ & $\begin{array}{l}\text { Shortest read } \\
\text { lengths, } \\
\text { still an } \\
\text { emerging } \\
\text { platform }\end{array}$ \\
\hline
\end{tabular}


Table 2 Comparison of first-, second-, and third-generation genomic sequencing

\begin{tabular}{llll}
\hline & First generation & Second generation & Third generation \\
\hline $\begin{array}{l}\text { Fundamental } \\
\text { technology }\end{array}$ & $\begin{array}{l}\text { Size-separation of specifically end-labeled } \\
\text { DNA fragments }\end{array}$ & Wash-and-scan SBS & $\begin{array}{l}\text { Single molecule real time } \\
\text { sequencing }\end{array}$ \\
\hline Resolution & $\begin{array}{l}\text { Averaged across many copies of the DNA } \\
\text { molecule }\end{array}$ & $\begin{array}{l}\text { Averaged across many copies of the DNA } \\
\text { molecule }\end{array}$ & Single DNA molecule \\
\hline $\begin{array}{l}\text { Current raw read } \\
\text { accuracy }\end{array}$ & High & High & Lower \\
\hline Current read length & $\begin{array}{l}\text { Moderate } \\
(800-1000 \text { bp) }\end{array}$ & $\begin{array}{l}\text { Short (generally much shorter than Sanger } \\
\text { sequencing) }\end{array}$ & $>1000$ bp \\
\hline Current throughput & Low & High & High \\
\hline Current cost & High cost per base, & $\begin{array}{l}\text { Low cost per base, } \\
\text { High cost per run }\end{array}$ & Low cost per base, \\
\hline $\begin{array}{l}\text { RNA-sequencing } \\
\text { method }\end{array}$ & cDNA sequencing & CDNA sequencing & Direct RNA sequencing \\
\hline Time to result & Hours & Days & $<1$ day \\
\hline Sample preparation & Moderately complex, PCR amplification is not & Complex, PCR amplification is required & Various \\
\hline Data analysis & Routine & $\begin{array}{l}\text { Complex } \\
\text { (due to large data volumes \& short reads) }\end{array}$ & Complex \\
\hline Primary results & Base calls with quality values & Base calls with quality values & Base calls with quality values \\
\hline
\end{tabular}

Adapted from Schadt, et al. Hum Mol Genet $2010^{13}$

given study will determine which NGS platform is used. For example, due to its significant expense, whole genome sequencing, in which the entire genome is sequenced, is an arduous and costly methodology to adopt. However, for collecting large amounts of DNA sequence data from individual human subjects, the more expensive Sanger sequencing is still widely used because of its capacity for longer read lengths [15]. An important limitation, however, is the extremely large sample size required to provide adequate power for data analysis in most whole genome studies. Therefore, more cost-efficient methods are needed and the scope of these studies is often driven by the availability of resources and funding. Whole genome and also exome sequencing (in which only the transcribed regions of the genome are sequenced) both attempt to find polymorphisms that may predict drug outcome or explain mono-genic disorders. At the other end of the spectrum, transcriptome sequencing detects gene expression changes and may be used to identify the effects of a drug on patients (pharmacogenomics). For these types of studies, NGS is now rapidly replacing microarray expression analysis, given the capacity of NGS platforms to sequence more complex and smaller genomes [16].

Recent whole genome studies have used NGS to gain insight into genomic markers of disease. An excellent example using whole genome sequencing was reported by Mardis et al, in which 12 somatic mutations within coding sequences and 52 somatic point mutations in conserved regions of patients with acute myeloid leukemia (AML) were identified [17]. Investigators were able to identify two common genetic variants previously linked with AML and two novel markers, one of which was in a non-coding region which demonstrated regulatory potential. Without sequencing the entire genome, investigators may not have understood the influence of non-coding regions on regulatory function in AML, highlighting a potential benefit of this approach. Other more recent areas with promising breakthroughs using whole-genome sequencing include: the development of targeted chemotherapies for lung adenocarcinoma, single-step capture and sequencing of natural DNA for the detection of BRCA1 mutations, and the identification of MYO1E mutations in childhood familial focal segmental glomerulosclerosis.[18-20]

Exome sequencing has been used to gain insight and determine genetic abnormalities in congenital defects. This approach has been favored for a number of reasons. First, this technique requires only about $5 \%$ as much sequencing as a whole genome. In total, there are about 180,000 exons found in the human genome. It is estimated that the protein coding regions of the human genome constitute about $85 \%$ of the disease-causing mutations. A pivotal study reported in 2006 identified a point mutation in Freeman-Sheldon Syndrome [21]. After excluding common variants using HapMap, investigators identified the $M Y H 3$ gene mutation by sequencing four individuals with the disease. Since then, exome sequencing has been used as a popular approach to identify rare Mendelian disorders [22-24]. These breakthroughs have led to the more widespread use of exome sequencing to study and identify specific mutations in 
more common complex diseases such as breast cancer, [25] familial lipid disorders, [26,27] Parkinson's Disease, $[28,29]$ and autism spectrum disorder [30,31].

Transcriptome sequencing encompasses experiments including small RNA profiling and discovery, mRNA transcript expression analysis (full-length mRNA, expressed sequence tags and ditags, and allele-specific expression) and the sequencing and analysis of fulllength mRNA transcripts. Transcriptome investigation has included the areas of novel gene discovery, gene space identification in novel genomes, assembly of fulllength genes, SNPs, and insertion-deletion and splicevariant discovery. Transcriptome sequencing has evolved as a robust technique for evaluating gene expression changes from either healthy individuals who develop disease, or within diseases themselves, such as breast cancer and malignant metastases within the same patient [32]. One application of this technology involved a study of lobular breast carcinoma, in which researchers found 32 somatic non-synonymous coding mutations present in the metastasis, and measured the frequency of these somatic mutations in DNA from the primary tumor of the same patient, which arose 9 years earlier. Five of the 32 mutations (in $A B C B 11, H A U S 3$, $S L C 24 A 4, S N X 4$ and $P A L B 2)$ were prevalent in the DNA of the primary tumor removed at diagnosis 9 years earlier; six (in KIF1C, USP28, MYH8, MORC1, KIAA1468 and RNASEH2A) were present at lower frequencies $(1-13 \%) ; 19$ were not detected in the primary tumor, and two were undetermined [33]. The combined analysis of genome and transcriptome data revealed two new RNA-editing events that recode the amino acid sequence of SRP9 and COG3. Taken together, these data show that transcriptome sequencing was useful in identifying single nucleotide mutational heterogeneity, which can be a property of low or intermediate grade primary breast cancers, and that significant evolution can occur with disease progression. Most recently, researchers have used transcriptome sequencing approaches to identify functional microRNA involved in endometriosis, and diagnostic and prognostic signatures from the small non-coding RNA transcriptome in prostate cancer [34-36].

\section{Distribution of Clinical Trials using Genomic Sequencing}

Perhaps the best resource for identifying and tracking the growing number of studies now using genomic sequencing is ClinicalTrials.gov [37]. This website is a registry of federally and privately supported clinical trials (experimental and observational) conducted in the United States and around the world. Since 2007, the Food and Drug Administration mandated registration and results reporting for clinical trials of drugs, biologics, and devices (US Public Law 110-85). Based upon our recent search of the website (July 2011) there were 35 registered studies in which "genomic sequencing" was included in the protocol as either a primary or secondary outcome measure. Eighteen of these studies are actively recruiting patients and six have reportedly been completed. Figures 1 and 2 show the worldwide and U. S. distributions of studies involving genomic sequencing that are currently reported on ClinicalTrials.gov. The majority of these are concentrated in the U.S. (20 studies), followed by Europe ( 9 studies). The highest concentrations of U.S. trials are based in California and Maryland. Clusters of activity appear to be dependent upon the types of research centers located within major academic institutions, but this is not necessarily true for all states.

\section{Types of Clinical Studies}

There is a wide range of studies that are now utilizing genomic sequencing technology. The list of conditions and diseases involved is a clear indicator of the growing interest in understanding the role of genetic predisposition in human disease. According to ClinicalTrials.gov, genomic sequencing technologies have been incorporated into studies on 16 categories of disease conditions. Table 3 lists these categories and examples of associated conditions. There is significant overlap, such that the majority of studies fall under the three most generalized categories involving blood/lymph, cancers/neoplasms, and immune system diseases. The studies most representative of the movement towards genomic sequencing research are those involving cancer biomarker research, including adulthood and childhood leukemias/lymphoma, congenital syndromes and central nervous system disorders, HIV/AIDS research, and associated drug developments.

According to our search, there were six recently completed clinical studies that have proposed genomic sequencing as an outcome measure at the time of this review. In France, an observational study of molecular and metabolic markers in oligodendrogliomas was recently completed with tumor collection from 189 pediatric and adult patients (NCT00213876). Researchers will use these tumor samples to identify diagnostic molecular and metabolic markers that could be used as a signature to characterize benign versus more aggressive tumor histologies. Genomic sequencing and serial analysis of genomic expression results will be correlated to survival and clinical features of oligodendrogliomas, medulloblastomas, and gliomas. A recently completed epidemiological study on the distribution of insulin-like growth factor-1 (IGF-1) deficiency in children with idiopathic short stature will investigate candidate genes and DNA changes that are potentially associated with short 


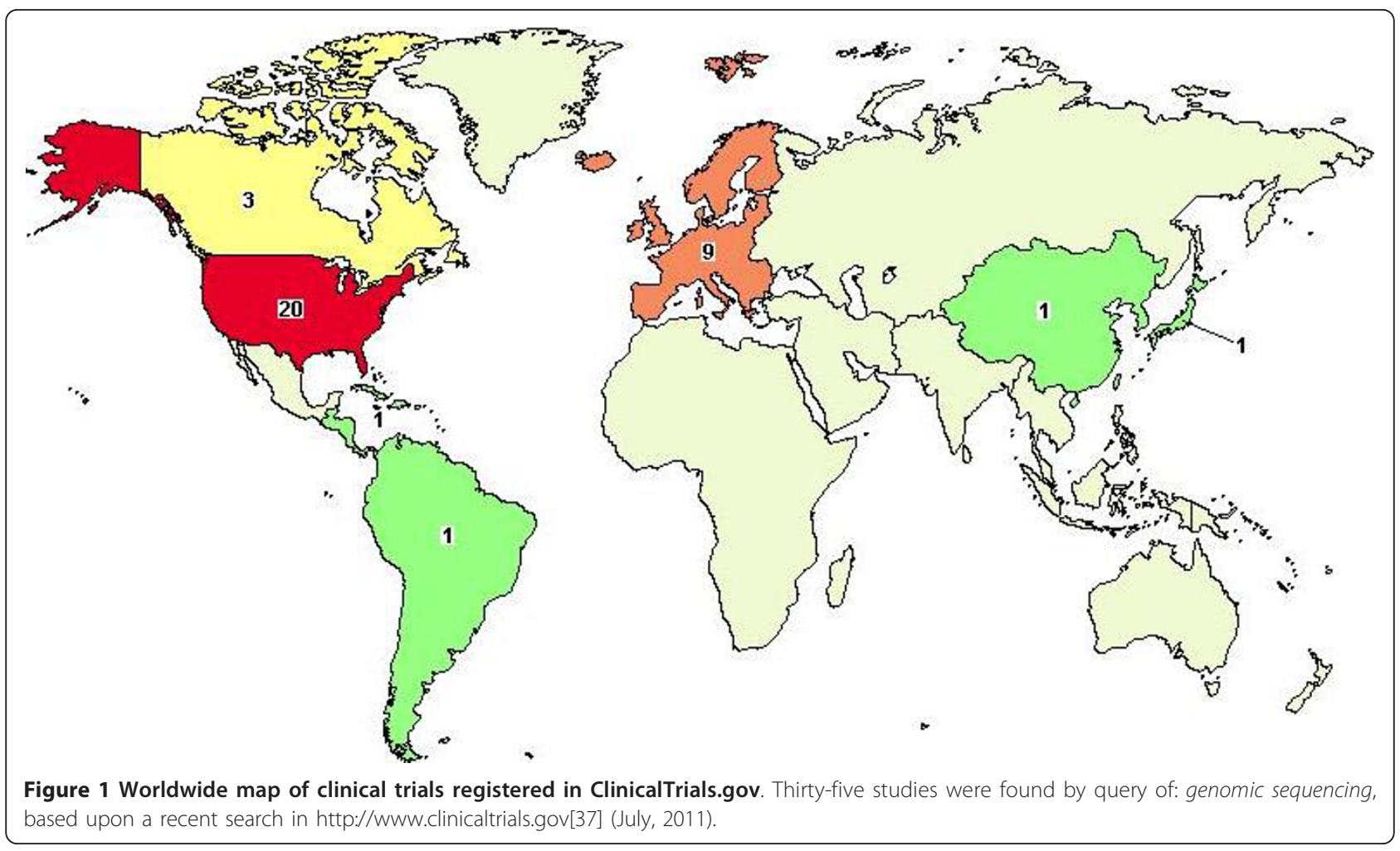

stature. DNA regions identified during genome-wide scan will be further mapped at higher resolution using DNA-sequencing (NCT00710307).

Genomic sequencing has also been incorporated as a secondary outcome measure in a few recently completed experimental studies: Investigators in France conducted an open label trial to evaluate the biological effect of Tarceva for patients with epidermoid carcinoma. A frozen tissue bank was generated for genomic sequencing study of tumorous epidermal growth factor receptor (EGF-R)

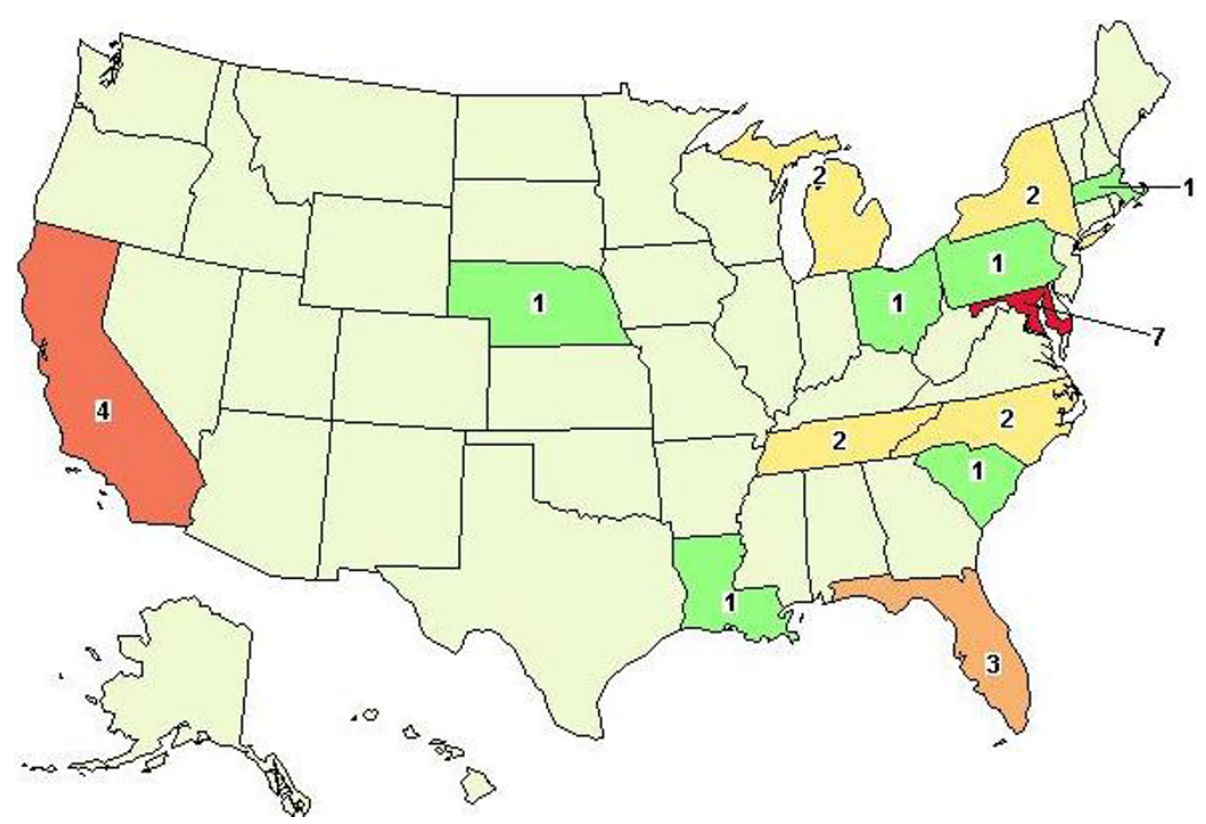

Figure 2 U.S. distribution of registered clinical trials that disclose the use of genomic sequencing. In July, 2011, twenty studies reported incorporation of NGS technology. The majority of these studies were being conducted in California (4) and Maryland (7). 
Table 3 Condition categories and diseases studied utilizing genomic sequencing technology.

\begin{tabular}{|c|c|}
\hline Condition & Diseases \\
\hline Bacterial and Fungal Diseases & Mycoses, Osteitis, Pelvic Infection, Pelvic Inflammatory Disease, Proteus Infections \\
\hline Blood and Lymph Conditions & $\begin{array}{l}\text { Anemia, Blood Coagulation, Burkitt Lymphoma, Hodgkin Disease, Hemorrhagic, Hemoglobinopathies, Leukemias, } \\
\text { Lymphomas, Lymphoproliferative Disorders, Multiple Myeloma }\end{array}$ \\
\hline Cancers and Other Neoplasms & Adenocarcinoma, Neuroblastoma, Nevus, Osteosarcoma, Retinoblastoma, multiple neoplasms, carcinomas, etc. \\
\hline Digestive System Diseases & Digestive System Neoplasms, Duodenal Diseases, Gastroenteritis, Ileal, Jejunal, Stomach Diseases and Neoplasms \\
\hline $\begin{array}{l}\text { Diseases and Abnormalities at or } \\
\text { before Birth }\end{array}$ & $\begin{array}{l}\text { Multiple congenital anomalies, Cardiovascular Anomalies/Congenital Heart Disease, Inborn Diseases, } \\
\text { Hemoglobinopathies, Neurocutaneous Syndromes, Neurofibromatoses }\end{array}$ \\
\hline Ear, Nose, and Throat Diseases & Deafness, Hearing Disorders, Hearing Loss \\
\hline Eye Diseases & Retinoblastoma \\
\hline $\begin{array}{l}\text { Gland and Hormone Related } \\
\text { Diseases }\end{array}$ & Acromegaly, Endocrine Disorders, Dwarfism, Neoplasms, Hyperparathyroidism, Parathyroid and Pituitary Diseases \\
\hline Heart and Blood Diseases & Aortic Valve Stenosis, Arterial Occlusive Diseases, Cardiomyopathies, Coronary Artery Disease, Ml \\
\hline Immune System Diseases & $\begin{array}{l}\text { AIDS, Lymphomas, Hodgkin Disease, Immunoproliferative Disorders, Leukemias, Myelomas, Mycosis, } \\
\text { Macroglobulinemia }\end{array}$ \\
\hline $\begin{array}{l}\text { Muscle, Bone, and Cartilage } \\
\text { Diseases }\end{array}$ & Acromegaly, Bone Diseases, Dwarfism, Congenital Limb Anomalies, Musculoskeletal Abnormalities, Osteitis \\
\hline Nervous System Diseases & $\begin{array}{l}\text { ALS, Aphasias, Brain Neoplasms, CNS Diseases, Coma, Communication Disorders, Deafness, Dementia/Delirium, } \\
\text { Motor Neuron Diseases, Neurocutaneous Syndromes, Neurodegenerative Diseases, Neurofibromas/NF, } \\
\text { Neuromuscular Diseases, Pain, Speech Disorders, Spinal Cord Diseases }\end{array}$ \\
\hline $\begin{array}{l}\text { Skin and Connective Tissue } \\
\text { Diseases }\end{array}$ & Breast Diseases/Neoplasms, Neurocutaneous Syndromes \\
\hline Symptoms and General Pathology & $\begin{array}{l}\text { Coma, Communication, Deafness/Delirium, Hearing Disorders, Hemolysis, Inflammation, Ischemia, } \\
\text { Neurobehavioral, Pain, Sclerosis, Sepsis/Shock }\end{array}$ \\
\hline $\begin{array}{l}\text { Urinary Tract, Sexual Organs, \& } \\
\text { Pregnancy }\end{array}$ & $\begin{array}{l}\text { Adnexal Diseases, Renal Cell Carcinoma, Endometritis, Kidney Diseases, Pelvic Inflammatory Disease, Prostatic } \\
\text { Neoplasms, Urogenital Neoplasms, Uterine and Urologic Diseases, Wilm's Tumor }\end{array}$ \\
\hline Viral Diseases & AIDS, Burkitt Lymphoma, HIV Infections \\
\hline
\end{tabular}

structure and for modification of in situ gene expression induction with the drug by RNA microarray technology (NCT00144976). In an international phase II trial of Lapatinib in patients with relapsed or refractory inflammatory breast cancer, researchers will study tumor cell growth and survival by quantitative immunohistochemistry and by direct and genome-wide methods (e.g., direct sequencing and DNA microarray) in tumor tissue collected prior to and following 28 days of lapatinib monotherapy (NCT00105950). In the Dominican Republic, a Phase III randomized, double-blind, placebo-controlled study was completed in 2008 (200 infants) to investigate horizontal transmission of human rotavirus vaccine strain (Rotarix) (NCT00396630). Investigators are using genomic sequencing to analyze mutations in the vaccine strain after transmission.

Thirteen of the 35 studies were designed with genomic sequencing results as a primary outcome measure (Table 4). The most recently registered trial by the Eunice Kennedy Shriver National Institute of Child Health and Human Development (NICHD) will allow for exomic sequencing of participating NICHD patients and their family members. Included in this study are probands that are enrolled in an NICHD clinical protocol for which there is a suspicion of an underlying genetic cause for a disease for which they are being evaluated. Many other studies are capitalizing on up-andcoming NGS technology, including feasibility and pilot studies of solid tumors and leukemias, and whole genome sequencing studies for a wide array of congenital disorders, cardiovascular diseases, hematologic conditions and endocrine disorders. What is common in the diseases being studied is the potential for improved outcome with earlier diagnosis and treatment. Hence, translational researchers are recognizing the potential of genomic sequencing technology as an important diagnostic and screening tool in the clinical setting.

\section{Largest U.S. Patient Samples}

There are a few large-scale epidemiological studies that have begun to incorporate genomic sequencing as a major part of their observations. For example, the largest U.S. sample registered at the time of this review, sponsored by the National Cancer Institute (NCI), has enrolled 3,000 patients to study gene expression of lymphoma, leukemia, and multiple myeloma (NCT00339963). In this trial, DNA sequencing methods are being used to analyze base changes in the genome of the cancer cells. While there are 
Table 4 Active and completed studies using genomic sequencing results as the primary outcome measure (source: http://www.clinicaltrials.gov, July 2011)

\begin{tabular}{|c|c|c|c|}
\hline Study Title/Sponsor & $\begin{array}{l}\text { NCT \#/ } \\
\text { \# Enrolled/ } \\
\text { Start Date }\end{array}$ & Condition & Description \\
\hline $\begin{array}{c}\text { Next Generation to Identify Genetic Causes of } \\
\text { Disease in Patients Participating in NICHD Clinical } \\
\text { Protocols } \\
\text { NICHD }\end{array}$ & $\begin{array}{c}\text { NCT01375543 } \\
100 \\
\text { June } 2011\end{array}$ & $\begin{array}{l}\text { Genetic diseases } \\
\text { (pediatric) }\end{array}$ & $\begin{array}{l}\text { Use of DNA samples to conduct exome and genome } \\
\text { sequencing }\end{array}$ \\
\hline $\begin{array}{c}\text { Feasibility Clinical Study of Targeted and Genome- } \\
\text { Wide Sequencing } \\
\text { University Health Network, Toronto }\end{array}$ & $\begin{array}{l}\text { NCT01345513 } \\
100 \\
\text { March } 2011\end{array}$ & Solid Tumors & $\begin{array}{l}\text { Targeted and genome-wide sequencing of DNA to enable } \\
\text { molecular characterization of tumors. }\end{array}$ \\
\hline $\begin{array}{c}\text { Biomarkers in Tissue Samples from Patients with } \\
\text { High-Risk Wilms Tumor } \\
\qquad \mathrm{NCl}\end{array}$ & $\begin{array}{l}\text { NCT01118078 } \\
100 \\
\text { March } 2010\end{array}$ & Kidney Cancer & $\begin{array}{c}\text { Application of array-based methods and NGS to identify } \\
\text { candidate molecular targets }\end{array}$ \\
\hline $\begin{array}{c}\text { Whole Genome Medical Sequencing for Genome } \\
\text { Discovery } \\
\text { NHGRI }\end{array}$ & $\begin{array}{l}\text { NCT01087320 } \\
100 \\
\text { Feb } 2010\end{array}$ & $\begin{array}{l}\text { Congenital } \\
\text { Syndromes/ } \\
\text { Genetic } \\
\text { Disorders }\end{array}$ & $\begin{array}{c}\text { Using genomic sequencing to identify genetic causes of } \\
\text { disorders that are difficult to identify with existing } \\
\text { techniques }\end{array}$ \\
\hline $\begin{array}{c}\text { Studying DNA in Tumor Tissue Samples from } \\
\text { Patients with Localized or Metastatic Osteosarcoma } \\
\text { NCl }\end{array}$ & $\begin{array}{c}\text { NCT01062438 } \\
99 \\
\text { Jan } 2010\end{array}$ & Sarcoma & $\begin{array}{c}\text { Genomic expression profile in osteosarcoma tumor samples } \\
\text { using transcriptome sequencing }\end{array}$ \\
\hline $\begin{array}{l}\text { Genetics of Congenital Heart Disease } \\
\text { Nationwide Children's Hospital }\end{array}$ & $\begin{array}{c}\text { NCT01192048 } \\
1000 \\
\text { Dec } 2009 \\
\end{array}$ & $\begin{array}{l}\text { Congenital Heart } \\
\text { Disease }\end{array}$ & $\begin{array}{c}\text { Direct sequencing and/or microarray, whole-genome array } \\
\text { comparative genomic hybridization (CGH) }\end{array}$ \\
\hline $\begin{array}{c}\text { Integrated Whole-Genome Analysis of Hematologic } \\
\text { Disorders } \\
\text { Stanford University }\end{array}$ & $\begin{array}{l}\text { NCT01108159 } \\
100 \\
\text { Sept } 2009\end{array}$ & $\begin{array}{l}\text { Hematologic } \\
\text { Diseases }\end{array}$ & $\begin{array}{l}\text { Whole-genome analysis/high-throughput sequencing using } \\
\text { blood, bone marrow and skin biopsy samples }\end{array}$ \\
\hline $\begin{array}{l}\text { Study of Tissue Samples from Patients with } \\
\text { Lymphoma } \\
\text { NCl }\end{array}$ & $\begin{array}{l}\text { NCT00952809 } \\
300 \\
\text { March } 2009 \\
\end{array}$ & $\begin{array}{l}\text { Lymphoma; } \\
\text { Small Intestinal } \\
\text { Cancer }\end{array}$ & $\begin{array}{c}\text { Generation of genome-wide maps of the distribution of } \\
\text { nucleosomes and histone modifications as assessed by high } \\
\text { throughput sequencing (ChIP-Seq) }\end{array}$ \\
\hline $\begin{array}{l}\text { Genetics of Endocrine Tumours } \\
\text { Barts \& The London NHS Trust }\end{array}$ & $\begin{array}{l}\text { NCT00461188 } \\
150 \\
\text { March } 2007\end{array}$ & Acromegaly & Tumor samples studied using candidate gene sequencing \\
\hline $\begin{array}{l}\text { DNA Analysis of Tumor Tissue Samples from } \\
\text { Patients with Diffuse Brain Stem Glioma } \\
\text { St. Jude Children's Research Hospital }\end{array}$ & $\begin{array}{c}\text { NCT00899834 } \\
30 \\
\text { June } 2006\end{array}$ & $\begin{array}{l}\text { Brain \& CNS } \\
\text { Tumors }\end{array}$ & $\begin{array}{c}\text { Genome-wide expression of RNA in tumor samples using } \\
\text { gene expression profiling. Direct sequencing analysis of } \\
\text { tumor DNA }\end{array}$ \\
\hline $\begin{array}{c}\text { ClinSeq: A Large-Scale Medical Sequencing Clinical } \\
\text { Research Pilot Study } \\
\text { NHGRI }\end{array}$ & $\begin{array}{l}\text { NCT00410241 } \\
2000 \\
\text { Dec } 2006\end{array}$ & $\begin{array}{l}\text { Cardiovascular } \\
\text { Disease }\end{array}$ & Sequencing $\sim 400$ genes related to heart disease \\
\hline $\begin{array}{c}\text { Laboratory Study of Lymphoblasts in Young } \\
\text { Patients with High-Risk ALL } \\
\text { NCl }\end{array}$ & $\begin{array}{l}\text { NCT00896766 } \\
150 \\
\text { July } 2006\end{array}$ & Leukemia & $\begin{array}{l}\text { Pilot application of array-based methods and gene re- } \\
\text { sequencing to identify candidate molecular targets for ALL }\end{array}$ \\
\hline $\begin{array}{c}\text { Genome Expression in Lymphoma, Leukemia and } \\
\text { Multiple Myeloma } \\
\text { NCl }\end{array}$ & $\begin{array}{l}\text { NCT00339963 } \\
3000 \\
\text { Nov } 2001\end{array}$ & $\begin{array}{l}\text { Lymphoma, } \\
\text { Leukemia } \\
\text { Multiple } \\
\text { Myeloma }\end{array}$ & $\begin{array}{l}\text { Participating centers send samples to the } \mathrm{NCl} \text { for gene } \\
\text { expression profiling, array-based comparative genomic } \\
\text { hybridization and cancer gene re-sequencing. }\end{array}$ \\
\hline
\end{tabular}

several reports that have described the sequencing of whole genomes from a few patients, the much larger number of cases in this trial will allow researchers to identify biologically relevant patterns in humans [33,38-41]. The National Human Genome Research Institute (NHGRI) has enrolled 2,000 patients to examine genomic sequencing in clinical research on coronary artery disease (ClinSeq, NCT00410241). Researchers will start by sequencing about 400 genes related to heart disease, with the eventual goal of sequencing most or all of participants' genes. The National Institute of Allergy and Infectious Disease
(NIAID) has enrolled 1,200 patients to develop diagnostic tests for community acquired pneumonia (CAP) and septic shock (NCT00258869). In this study, advanced bioinformatic, metabolomic, and proteomic approaches will be used with mRNA sequencing to identify protein changes in blood samples that predict outcomes in sepsis and CAP.

\section{Ethical and Computational Challenges in Translational Medicine}

As the cost of NGS technology is becoming less of a limitation, several inherent challenges remain that must 
not be overlooked. Of utmost relevance to the translational investigator are the ethical, legal and social issues surrounding genomic sequencing. In a recent study conducted by Allen and Foulkes, 30 cancer genome sequencing studies were assessed to evaluate how these issues are being handled across different jurisdictions [42]. While they found a high degree of similarity in how cancer researchers engaged in these studies were protecting participant privacy, there were no consistent means across these studies for re-contacting participants, or for returning results and facilitating participant withdrawal. There was a strong trend towards both using samples for additional, unspecified research and sharing data with other investigators. Given the unique nature of genomic sequencing research, individuals and groups engaging in NGS clinical trials may benefit from human subjects training in these specific areas. However, it is apparent that better-defined consensus standards are still needed both nationally and internationally to prepare the growing number of researchers in this field $[43,44]$.

With the vast amounts of high-quality, complex data now being processed through NGS, an ongoing challenge for translational researchers remains: How do we deal with the computational complexities of analyzing this data? NGS can miss parts of the genome that may be clinically important. It detects mainly small polymorphisms, though it could be used to detect larger copy number variations. Multiple comparison and sample size issues remain an ongoing problem. In general, the computational complexities of properly handling genomic sequencing data have lagged behind the development of the technology. Such challenges may only be addressed through the development of innovative bioinformatic approaches, and through strategic collaboration and knowledgeable study design and implementation by translational investigators. Computerized technological advances are rapidly becoming in high demand [45]. Two promising areas that are being used to bridge the gap between genomics and the bedside are the development of biologically and medically focused text mining algorithms and the integration of the electronic medical record (EMR). Both may speed the process of collection and analysis of structured data. However, these methods require further development and ongoing validation, especially before applying the information in the clinical setting.

\section{Conclusion}

In summary, rapid advances in genomic sequencing have paved the way for the incorporation of NGS into clinical applications. With NGS technology there is much improved cost-effectiveness and more rapid turnover, two critical success factors that are highly appealing to clinical and translational investigators. In the past, studies that implement gene sequencing have been concentrated around major academic institutions, but this is not expected to continue in the future. With more readily available and cost-effective markets now capitalizing on complete human genome sequencing and analysis as an outsourced service, the use of this technology is likely to become more automated, with significant impact on national and international economies [46]. As illustrated in this review, there is an increasing use of genomic sequencing in the U.S. and worldwide, with a wide range of disease conditions now studied that may soon replace microarray approaches in the new era of bioinformatics. Since these technological approaches are highly applicable for both rare Mendelian and well as more complex and common diseases, the future of genomics is promising.

\section{Abbreviations}

AIDS: Acquired Immune Deficiency Syndrome; AML: Acute Myeloid Leukemia; CAP: Community Acquired Pneumonia; ChIP: Chromatin Immunoprecipitation; CNV: Copy Number Variant; DNA: Deoxyribonucleic Acid; EGF-R: Epidermal Growth Factor Receptor; EMR: Electronic Medical Record; GA: Genome Analyzer; HIV: Human Immunodeficiency Virus; IGF: Insulin-like Growth Factor; mRNA: messenger Ribonucleic Acid; NCl: National Cancer Institute; NGS: Next-Generation Sequencing; NHGRI: National Human Genome Research Institute; NIAID: National Institute of Allergy and Infectious Disease; NICHD: National Institute of Child Health and Human Development; RNA: Ribonucleic Acid; SNP: Single Nucleotide Polymorphism.

\section{Acknowledgements}

This project was supported in part by Award Number UL1RR025741 and 1UL1RR025011 from the Clinical and Translational Science Award (CTSA) program of the National Center for Research Resources (NCRR), National Institutes of Health. KM has received career development funding from the NCRR (KL2 RR025740) and the National Heart Lung Blood Institute (K23 HL093302).

\section{Author details}

${ }^{1}$ Department of Pediatrics, Division of Neonatology, Northwestern University Feinberg School of Medicine, Chicago, IL, USA. ${ }^{2}$ Department of Medicine, Division of Cardiology, Section of Electrophysiology, Northwestern University Feinberg School of Medicine, Chicago, IL, USA. ${ }^{3}$ Department of Radiology, Northwestern University Feinberg School of Medicine, Chicago, IL, USA. ${ }^{4}$ Biomedical Informatics Research Center, Marshfield Clinic Research Foundation, Marshfield, WI, USA.

\section{Authors' contributions}

KM conducted the research on the Distribution and Types of Clinical Trials, and was primarily responsible for preparing the initial draft of this

manuscript for submission, revisions, and for final editing. LI conducted the literature search on Genomics in Human Disease and prepared this section of the manuscript, in addition to critically revising the manuscript for important intellectual content. SM conducted the research on Human Genomic Sequencing and prepared the tables and written sections pertaining to NGS technology. SL is responsible for initiating the topic of this review, overseeing the conception and design, and critically revising for important intellectual content. All authors read and approved the final manuscript.

\section{Competing interests}

The authors declare that they have no competing interests to disclose. Dr. Mestan receives career development funding from NHLBI (K23 HL093302).

Received: 25 July 2011 Accepted: 30 December 2011

Published: 30 December 2011 


\section{References}

1. Heger M: Next-gen sequencing makes inroads into clinical applications in 2010.[http://www.genomeweb.com/sequencing/next-gen-sequencingmakes-inroads-clinical-applications-2010].

2. Bhinge AA, Kim J, Euskirchen GM, Snyder M, lyer VR: Mapping the chromosomal targets of STAT1 by Sequence Tag Analysis of Genomic Enrichment (STAGE). Genome Res 2007, 17(6):910-916.

3. Johnson DS, Mortazavi A, Myers RM, Wold B: Genome-wide mapping of in vivo protein-DNA interactions. Science 2007, 316(5830):1497-1502.

4. Mortazavi A, Williams BA, McCue K, Schaeffer L, Wold B: Mapping and quantifying mammalian transcriptomes by RNA-Seq. Nat Methods 2008 , 5(7):621-628

5. Wang ET, Sandberg R, Luo S, Khrebtukova I, Zhang L, Mayr C, Kingsmore SF, Schroth GP, Burge CB: Alternative isoform regulation in human tissue transcriptomes. Nature 2008, 456(7221):470-476

6. Harismendy O, Ng PC, Strausberg RL, Wang X, Stockwell TB, Beeson KY, Schork NJ, Murray SS, Topol EJ, Levy S, Frazer KA: Evaluation of next generation sequencing platforms for population targeted sequencing studies. Genome biology 2009, 10(3):R32.

7. Drmanac R, Sparks AB, Callow MJ, Halpern AL, Burns NL, Kermani BG, Carnevali P, Nazarenko I, Nilsen GB, Yeung G, Dahl F, Fernandez A, Staker B, Pant KP, Baccash J, Borcherding AP, Brownley A, Cedeno R, Chen L, Chernikoff D, Cheung A, Chirita R, Curson B, Ebert JC, Hacker CR, Hartlage R, Hauser $B$, Huang $S$, Jiang $Y$, Karpinchyk $V$, et al: Human genome sequencing using unchained base reads on self-assembling DNA nanoarrays. Science 2010, 327(5961):78-81

8. Hodges E, Xuan Z, Balija V, Kramer M, Molla MN, Smith SW, Middle CM, Rodesch MJ, Albert TJ, Hannon GJ, McCombie WR: Genome-wide in situ exon capture for selective resequencing. Nat Genet 2007, 39(12):1522-1527.

9. Porreca GJ, Zhang K, Li JB, Xie B, Austin D, Vassallo SL, LeProust EM Peck BJ, Emig CJ, Dahl F, Gao Y, Church GM, Shendure J: Multiplex amplification of large sets of human exons. Nat Methods 2007, 4(11):931-936

10. Kircher M, Kelso J: High-throughput DNA sequencing-concepts and limitations. Bioessays 2010, 32(6):524-536.

11. Allison M: Illumina's cut-price genome scan. Nature Biotechnology 2009 27.

12. Bennett ST, Barnes C, Cox A, Davies L, Brown C: Toward the 1,000 dollars human genome. Pharmacogenomics 2005, 6(4):373-382.

13. Schadt $E E$, Turner $S$, Kasarskis A: A window into third-generation sequencing. Human molecular genetics 2010, 19(R2):R227-240.

14. Rasko DA, Webster DR, Sahl JW, Bashir A, Boisen N, Scheutz F, Paxinos EE, Sebra R, Chin CS, Iliopoulos D, Klammer A, Peluso P, Lee L, Kislyuk AO, Bullard J, Kasarskis A, Wang S, Eid J, Rank D, Redman JC, Steyert SR, Frimodt-Moller J, Struve C, Petersen AM, Krogfelt KA, Nataro JP, Schadt EE, Waldor MK: Origins of the E. coli strain causing an outbreak of hemolytic-uremic syndrome in Germany. N Engl J Med 2011, 365(8):709-717.

15. Biesecker LG, Mullikin JC, Facio FM, Turner C, Cherukuri PF, Blakesley RW, Bouffard GG, Chines PS, Cruz P, Hansen NF, Teer JK, Maskeri B, Young AC, Manolio TA, Wilson AF, Finkel T, Hwang P, Arai A, Remaley AT, Sachdev V, Shamburek R, Cannon RO, Green ED: The ClinSeq Project: piloting largescale genome sequencing for research in genomic medicine. Genome Res 2009, 19(9):1665-1674.

16. Xu G, Fewell C, Taylor C, Deng N, Hedges D, Wang X, Zhang K, Lacey M, Zhang H, Yin Q, Cameron J, Lin Z, Zhu D, Flemington EK: Transcriptome and targetome analysis in MIR155 expressing cells using RNA-seq. Rna 2010, 16(8):1610-1622

17. Mardis ER, Ding L, Dooling DJ, Larson DE, McLellan MD, Chen K, Koboldt DC, Fulton RS, Delehaunty KD, McGrath SD, Fulton LA, Locke DP, Magrini VJ, Abbott RM, Vickery TL, Reed JS, Robinson JS, Wylie T, Smith SM, Carmichael L, Eldred JM, Harris CC, Walker J, Peck JB, Du F, Dukes AF, Sanderson GE, Brummett AM, Clark E, McMichael JF, et al: Recurring mutations found by sequencing an acute myeloid leukemia genome. $N$ Engl J Med 2009, 361(11):1058-1066.

18. Thompson JF, Reifenberger JG, Giladi E, Kerouac K, Gill J, Hansen E, Kahvejian A, Kapranov P, Knope T, Lipson D, Steinmann KE, Milos PM: Single-step capture and sequencing of natural DNA for detection of BRCA1 mutations. Genome Res 2011.
19. Greulich $\mathrm{H}$ : The genomics of lung adenocarcinoma: opportunities for targeted therapies. Genes Cancer 2010, 1(12):1200-1210.

20. Mele C, latropoulos P, Donadelli R, Calabria A, Maranta R, Cassis P, Buelli S, Tomasoni S, Piras R, Krendel M, Bettoni S, Morigi M, Delledonne M, Pecoraro C, Abbate I, Capobianchi MR, Hildebrandt F, Otto E, Schaefer F, Macciardi F, Ozaltin F, Emre S, Ibsirlioglu T, Benigni A, Remuzzi G, Noris M: MYO1E Mutations and Childhood Familial Focal Segmental Glomerulosclerosis. N Engl J Med 2011.

21. Toydemir RM, Rutherford A, Whitby FG, Jorde LB, Carey JC, Bamshad MJ: Mutations in embryonic myosin heavy chain (MYH3) cause FreemanSheldon syndrome and Sheldon-Hall syndrome. Nat Genet 2006, 38(5):561-565

22. Amberger J, Bocchini C, Hamosh A: A new face and new challenges for Online Mendelian Inheritance in Man (OMIM(R)). Hum Mutat 2011 32(5):564-567

23. Ku CS, Naidoo N, Pawitan Y: Revisiting Mendelian disorders through exome sequencing. Hum Genet 2011, 129(4):351-370.

24. Buckingham KJ, Lee C, Bigham AW, Tabor HK, Dent KM, Huff CD, Shannon PT, Jabs EW, Nickerson DA, Shendure J, Bamshad MJ: Exome sequencing identifies the cause of a mendelian disorder. Nat Genet 2010, 42(1):30-35.

25. Zhao Q, Kirkness EF, Caballero OL, Galante PA, Parmigiani RB, Edsall L, Kuan S, Ye Z, Levy S, Vasconcelos AT, Ren B, de Souza SJ, Camargo AA, Simpson AJ, Strausberg RL: Systematic detection of putative tumor suppressor genes through the combined use of exome and transcriptome sequencing. Genome Biol 2010, 11(11):R114

26. Rios J, Stein E, Shendure J, Hobbs HH, Cohen JC: Identification by wholegenome resequencing of gene defect responsible for severe hypercholesterolemia. Hum Mol Genet 2010, 19(22):4313-4318.

27. Musunuru K, Pirruccello JP, Do R, Peloso GM, Guiducci C, Sougnez C, Garimella KV, Fisher S, Abreu J, Barry AJ, Fennell T, Banks E, Ambrogio L, Cibulskis K, Kernytsky A, Gonzalez E, Rudzicz N, Engert JC, DePristo MA, Daly MJ, Cohen JC, Hobbs HH, Altshuler D, Schonfeld G, Gabriel SB, Yue P, Kathiresan S: Exome sequencing, ANGPTL3 mutations, and familial combined hypolipidemia. The New England journal of medicine 2010, 363(23):2220-2227

28. Vilarino-Guell C, Wider C, Ross OA, Dachsel JC, Kachergus JM, Lincoln SJ, Soto-Ortolaza Al, Cobb SA, Wilhoite GJ, Bacon JA, Behrouz B, Melrose HL, Hentati E, Puschmann A, Evans DM, Conibear E, Wasserman WW, Aasly JO, Burkhard PR, Djaldetti R, Ghika J, Hentati F, Krygowska-Wajs A, Lynch T, Melamed E, Rajput A, Rajput AH, Solida A, Wu RM, Uitti RJ, et al: VPS35 Mutations in Parkinson Disease. Am J Hum Genet 2011, 89(1):162-167.

29. Zimprich A, Benet-Pages A, Struhal W, Graf E, Eck SH, Offman MN, Haubenberger D, Spielberger S, Schulte EC, Lichtner P, Rossle SC, Klopp N Wolf E, Seppi K, Pirker W, Presslauer S, Mollenhauer B, Katzenschlager R, Foki T, Hotzy C, Reinthaler E, Harutyunyan A, Kralovics R, Peters A, Zimprich F, Brucke T, Poewe W, Auff E, Trenkwalder C, Rost B, et al: A Mutation in VPS35, Encoding a Subunit of the Retromer Complex, Causes Late-Onset Parkinson Disease. Am J Hum Genet 2011, 89(1):168-175

30. Betancur C: Etiological heterogeneity in autism spectrum disorders: more than 100 genetic and genomic disorders and still counting. Brain Res 2011, 1380:42-77.

31. O'Roak BJ, Deriziotis P, Lee C, Vives L, Schwartz JJ, Girirajan S, Karakoc E, Mackenzie AP, Ng SB, Baker C, Rieder MJ, Nickerson DA, Bernier R, Fisher SE, Shendure J, Eichler EE: Exome sequencing in sporadic autism spectrum disorders identifies severe de novo mutations. Nat Genet 2011, 43(6):585-589

32. Heger M: Transcriptome Sequencing Becoming Key Approach to Study Disease and Guide Treatment.[http://www.genomeweb.com/sequencing/ transcriptome-sequencing-becoming-key-approach-study-disease-and-guidetreatment].

33. Shah SP, Morin RD, Khattra J, Prentice L, Pugh T, Burleigh A, Delaney A, Gelmon K, Guliany R, Senz J, Steidl C, Holt RA, Jones S, Sun M, Leung G, Moore R, Severson T, Taylor GA, Teschendorff AE, Tse K, Turashvili G, Varhol R, Warren RL, Watson P, Zhao Y, Caldas C, Huntsman D, Hirst M, Marra MA, Aparicio S: Mutational evolution in a lobular breast tumour profiled at single nucleotide resolution. Nature 2009, 461(7265):809-813.

34. Hawkins SM, Creighton CJ, Han DY, Zariff A, Anderson ML, Gunaratne PH, Matzuk MM: Functional microRNA involved in endometriosis. Mol Endocrinol 2011, 25(5):821-832. 
35. Kannan K, Wang L, Wang J, Ittmann MM, Li W, Yen L: Recurrent chimeric RNAs enriched in human prostate cancer identified by deep sequencing. Proc Natl Acad Sci USA 2011, 108(22):9172-9177.

36. Martens-Uzunova ES, Jalava SE, Dits NF, van Leenders GJ, Moller S, Trapman J, Bangma CH, Litman T, Visakorpi T, Jenster G: Diagnostic and prognostic signatures from the small non-coding RNA transcriptome in prostate cancer. Oncogene 2011.

37. ClinicalTrials.gov: A service of the U.S. National Institutes of Health. [http://www.clinicaltrials.gov].

38. Campbell PJ, Stephens PJ, Pleasance ED, O'Meara S, Li H, Santarius T, Stebbings LA, Leroy C, Edkins S, Hardy C, Teague JW, Menzies A, Goodhead I, Turner DJ, Clee CM, Quail MA, Cox A, Brown C, Durbin R, Hurles ME, Edwards PA, Bignell GR, Stratton MR, Futreal PA: Identification of somatically acquired rearrangements in cancer using genome-wide massively parallel paired-end sequencing. Nat Genet 2008, 40(6):722-729.

39. Chapman MA, Lawrence MS, Keats JJ, Cibulskis K, Sougnez C, Schinzel AC, Harview CL, Brunet JP, Ahmann GJ, Adli M, Anderson KC, Ardlie KG, Auclair D, Baker A, Bergsagel PL, Bernstein BE, Drier Y, Fonseca R, Gabriel SB, Hofmeister CC, Jagannath S, Jakubowiak AJ, Krishnan A, Levy J, Liefeld T, Lonial S, Mahan S, Mfuko B, Monti S, Perkins LM, et al: Initial genome sequencing and analysis of multiple myeloma. Nature 2011 471(7339):467-472.

40. Lee W, Jiang Z, Liu J, Haverty PM, Guan Y, Stinson J, Yue P, Zhang Y, Pant KP, Bhatt D, Ha C, Johnson S, Kennemer MI, Mohan S, Nazarenko I, Watanabe C, Sparks AB, Shames DS, Gentleman R, de Sauvage FJ, Stern H, Pandita A, Ballinger DG, Drmanac R, Modrusan Z, Seshagiri S, Zhang Z: The mutation spectrum revealed by paired genome sequences from a lung cancer patient. Nature 2010, 465(7297):473-477.

41. Ley TJ, Mardis ER, Ding L, Fulton B, McLellan MD, Chen K, Dooling D, Dunford-Shore BH, McGrath S, Hickenbotham M, Cook L, Abbott R, Larson DE, Koboldt DC, Pohl C, Smith S, Hawkins A, Abbott S, Locke D, Hillier LW, Miner T, Fulton L, Magrini V, Wylie T, Glasscock J, Conyers J, Sander N, Shi X, Osborne JR, Minx P, et al: DNA sequencing of a cytogenetically normal acute myeloid leukaemia genome. Nature 2008, 456(7218):66-72.

42. Allen C, Foulkes WD: Qualitative thematic analysis of consent forms used in cancer genome sequencing. BMC Med Ethics 2011, 12:14.

43. Clayton EW, Ross LF: Implications of disclosing individual results of clinical research. Jama 2006, 295(1):37, author reply 37-38.

44. Shalowitz DI, Miller FG: Disclosing individual results of clinical research: implications of respect for participants. Jama 2005, 294(6):737-740.

45. Fernald GH, Capriotti E, Daneshjou R, Karczewski K, Altman RB: Bioinformatics challenges for personalized medicine. Bioinformatics 2011, 27(13):1741-1748.

46. Aldhous $\mathrm{P}$ : Where robots labour to overcome genetic disease. NewScientist 2011, 14.

\section{Submit your next manuscript to BioMed Central and take full advantage of:}

- Convenient online submission

- Thorough peer review

- No space constraints or color figure charges

- Immediate publication on acceptance

- Inclusion in PubMed, CAS, Scopus and Google Scholar

- Research which is freely available for redistribution

Submit your manuscript at www.biomedcentral.com/submit
Biomed Central 